\title{
Rehydration of Fraser Fir Christmas Trees: Effect of Time since Cutting
}

\author{
L. Eric Hinesley ${ }^{1}$ and Layne K. Snelling ${ }^{2}$ \\ Department of Horticultural Science, North Carolina State University, \\ Raleigh, NC 27695- 7609
}

\author{
Scott Goodman \\ Mountain Research Station, 516 Test Farm Road, Waynesville, \\ NC 28786-4016
}

Additional index words. Abies fraseri, xylem pressure potential

To maintain the freshness of cut Christmas trees, it is important to make a fresh cut on the base of the trunk just before displaying the tree in a stand containing water (Ahrens and Stephens, 1975; Chastagner, 1990; Hinesley and Huxster, 1991; Van Wagner, 1963). It is also important to provide adequate water daily in the stand because trees can consume up to 1 liter day ${ }^{-1}$ for each $2.5 \mathrm{~cm}$ of trunk diameter (Chastagner, 1990). For most Christmas tree species, it has not been determined how much time can elapse after the trunk is cut before rehydration capacity decreases. Fresh Douglas fir [Pseudotsugu mensiezii (Mirb.) Franco] Christmas trees can dry 24 to $48 \mathrm{~h}$ before rehydration capacity is noticeably reduced (Chastagner, 1990). Our objective was to examine the rehydration capacity of Fraser fir [Abies fraseri (Pursh) Poir.] Christmas trees, as affected by time since cutting.

Thirty-two Fraser fir Christmas trees were selected at the Mountain Research Station, Waynesville, N.C. Trees were 1.5 to $1.8 \mathrm{~m}$ tall and of medium to heavy crown density, with fresh weights of 6 to $12 \mathrm{~kg}$. Four trees were cut at 0900 HR on 18 Dec. 1990 (time $=0$ ), and the bases stood in tap water within $20 \mathrm{sec}$ after cutting. Fresh weights were determined on these control trees within $15 \mathrm{~min}$ after cutting. The remaining 28 trees then were cut as quickly as possible in groups of four per treatment, with the time of cutting noted for each group. Throughout processing, cut surfaces of trunks were kept clean and unbruised.

All trees were transported to a nearby barn and fresh weights recorded. Trees were stored in a horizontal position, not more than two trees deep, on a room-length table. Temperature and relative humidity were $22 \pm 2 \mathrm{C}$,

Received for publication 4 Nov. 1991. Accepted for publication 6 May 1992. This research was funded by the North- Carolina Agricultural Research Service INCARS). Raleigh. NC 276957643. Use of trade names in this publication does not imply endorsement by the NCARS, or criticism of similar products not named. The cost of publishing this paper was defrayed in part by the payment of page charges. Under postal regulations, this paper therefore must be hereby marked $a d$ vertisement solely to indicate this fact. 'Professor.

${ }^{2}$ Research Technician. and $45 \% \pm 5 \%$, respectively. The room was dimly lit by incandescent bulbs between 0800 and 1700 HR each day.

Four trees were stood with bases in water after 0 to $48 \mathrm{~h}$. Fresh weight and xylem pressure potential $(\Psi)$, were recorded when each tree was returned to water. Pressure potential was measured on one or two small twigs, using a pressure chamber (PMS Instruments, Corvallis, Ore.). Fresh weights and $\Psi$ were determined periodically for each tree until 2 Jan. 1991, when the experiment was terminated.

In a second experiment, 32 trees from the same plantation were cut on 4 Feb. 1991 and processed as previously described. Time intervals for returning trees to water were 0 , $2,4,6,8,10,13$, and 15 days. Xylem pressure potential was initially determined on six randomly selected trees (time $=0$ ); thereafter, on each tree when i) it was returned to water, and ii) 1 week later. Tree fresh weights were determined at these same times. Temperature was set at $22 \mathrm{C}$ but occasionally dropped to $12 \mathrm{C}$ for several hours, due to equipment problems. Relative humidity was $50 \% \pm 15 \%$, and lighting was as previously described.

In the first experiment, initial $\Psi$ averaged $-0.7 \mathrm{MPa}$, and trees dried to about - 2.8 $\mathrm{MPa}$ in 2 days (data not shown). After placement in water, 28 trees rehydrated to $\Psi$ values of -0.45 to $-0.95 \mathrm{MPa}$; four others were slightly drier, but there was no relation to treatment. It was apparent that a wider time interval should have been tested.

In the second experiment, fresh weight decreased linearly with time, reaching $\approx 73 \%$ of the initial value after 15 days (Fig. 1A). Trees placed in water 56 days after cutting rehydrated to fresh weights $296 \%$ of initial values. Extent of rehydration decreased with increasing storage time; the 15-day storage treatment reached only $86 \%$ of initial fresh weight after 1 week in water.

In the second experiment, $\Psi$ was initially $-0.8 \mathrm{MPa}$, and decreased to $-4.1 \mathrm{MPa}$ after 15 days of storage (Fig. 1B). Trees placed in water 56 days after cutting rehydrated to $\Psi$ of -0.64 to $-0.95 \mathrm{MPa}$. Those dried 8 to 13 days had a final $\Psi$ of -1.1 to -1.3 $\mathrm{MPa}$ after 1 week in water, compared with $-2.0 \mathrm{MPa}$ for trees stored 15 days. Because $-4.1 \mathrm{MPa}$ (15 days of storage) was ap-
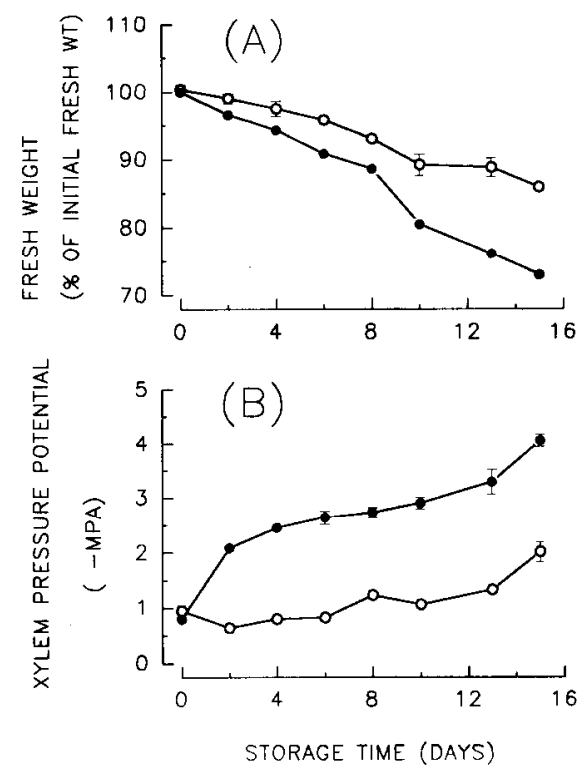

Fig. 1. Rehydration of Fraser fir Christmas trees as affected by storage time following cutting. (A) Fresh weight (percentage of initial fresh weight) immediately before placement in water ( $)$ ); 7 days later ( $\mathrm{O}$ ). (B) Xylem pressure potential immediately before placement in water ( ) 7 days later ( $\mathrm{O}$ ). Vertical bars, \pm se. Trunks were not recut when trees were placed in water.

proaching the critical moisture content of -4.5 MPa (Hinesley, 1984), rehydration probably would have decreased sharply with additional drying beyond 15 days. Needle drop was negligible in both experiments.

Fraser fir Christmas trees (freshly cut; stored indoors at $22 \mathrm{C}$ for up to 6 days) rehydrated to preharvest moisture levels when placed in water. This result undermines the common belief that all xylem cells quickly occlude with air following cutting, seriously impeding rehydration. Although it is advisable to cut a disk ( 1 to $2 \mathrm{~cm}$ thick) off the base of the trunk before standing a tree in water, adequate rehydration of fresh trees appears possible for several days after the cut is made. This finding agrees with results for Douglas fir, which can dry up to 2 days before rehydration capacity is noticeably reduced (Chastagner, 1990). Evidently, the capacity to rehydrate depends more on a tree's moisture status than the time since cutting.

\section{Literature Cited}

Ahrens, J.F. and G.R. Stephens. 1975. The effects of additives on freshness and flammability of Christmas trees. Conn. Agr. Expt. Sta. Bul. 760.

Chastagner, G. 1990. Keeping cut trees fresh Northwest Lookout (Northwest Christmas Tree Assn.) 23(3):32-34, 37-40,42-44.

Hinesley, L.E. 1984. Measuring freshness of cut Fraser fir Christmas trees. HortScience 19:860862.

Hinesley, L.E. and W.T. Huxster, Jr. 1991. Retail merchandising of North Carolina Fraser fir. Christmas Tree Notes Cl-N-17, N.C. Coop. Ext. Serv., Raleigh.

Van Wagner, C.E. 1963. Flammability of Christmas trees. Pub. 1034, Canada Dept. For., Ottawa. 